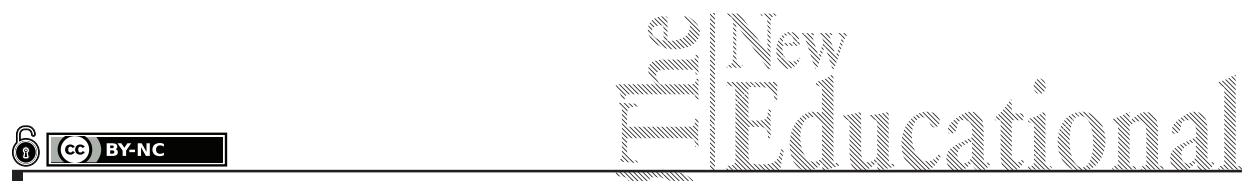

Miljana S. Pavicevic, Tijana Lj. Zivkovic

Serbia

\title{
Parenting Styles as Predictors of Adolescents' Self-Efficacy and Subjective Well-Being
}

DOI: 10.15804/tner.2021.65.3.02

\begin{abstract}
The aim of the research was to determine the predictive power of parenting styles in predicting subjective well-being and self-efficacy as aspects of adolescent mental health. The sample consisted of 270 students from four high schools in Serbia, aged 16 and 17. The research was conducted during March and April 2021, and research methods that were used are descriptive statistics, correlation analysis and regression analysis. The authoritative parental educational style contributes to the development of adolescents' experience of self-efficacy and subjective well-being. Authoritative parents - through high warmth and control - provide the child with an optimal environment for development.
\end{abstract}

Keywords: parenting styles, adolescents, mental health

\section{Introduction}

The role of parents in the development of a child's personality is undoubtedly primary. The family and the family context are of great importance for the child's growth and the formation of certain personality traits, as well as value systems. A child from the family can carry basic security and trust, which makes him resistant to future stresses (Pavicevic, 2020).

\section{Parenting styles}

Parenting styles can be defined as a consistent way of parents' behavior, which will bring educational goals in the best way through educational procedures, 
without, above all, disturbing the emotional relationship towards the child. Diana Baumrind (1966) made a great contribution to the research of educational styles, defining three different educational styles: authoritarian or rigid-strict style, then authoritative or democratic-consistent style and permissive or compliant educational style, and later defined the fourth educational style: neglectful or uncommitted educational style (Baumrind, 1991). Authoritarian or rigid-strict educational style is characterized by high control and low warmth. The main educational goals are learning self-control and obedience, where parents are the ones who set the requirements and set the rules, which they do not need to explain. The most important task of this educational style is setting boundaries and rules, and violations are often punished physically. Children growing up in an autocratic environment are changeable, withdrawn and irritable (Baumrind, 1968) which makes their socialization and independence more difficult (Belsky, Domitrovich \& Crnic, 1997). Authoritative or democratically-consistent educational style includes high demands, adjusted to the child's age, boundaries and supervision, but also high warmth and support. The main educational goals are to develop the child's curiosity, creativity, motivation and independence. Children who grow up in an authoritarian environment are spontaneous and freely express thoughts and feelings (Baumrind, 1968), they are self-confident, with good self-control and a desire to affirm themselves (Belsky, Domitrovich \& Crnic, 1997). Permissive or compliant upbringing style is characterized by low control, and high warmth and support. Parents meet every child's request. The permissive parent does not punish but accepts the child's impulses, desires, and activities (Baumrind, 1966). The decisions are made together with the child and rules of the family are explained. However, too much freedom in young children creates a feeling of insecurity, an inability encourages impulsive and aggressive behavior of the child (Baumrind, 1968). Neglecting or non-engaged parenting style refers to a situation when control is low, but both warmth and support are low, i.e. when parents usually do not pay attention to the child's behavior. Parents either reject the child or do not have the time and energy to take care of him. The child reacts to this attitude of the parents with hostility and resistance, and because of that, the child fails to acquire appropriate social competencies, and fails at school (Baumrind, 1991). Baumrind (Baumrind \& Thompson, 2002) concludes that the authoritative educational style is the most effective in achieving a high level of children's individuality and togetherness. If there are different alternatives to an authoritarian parenting style in different cultural contexts, no study has shown that an authoritative parenting style can be harmful or less effective (Belsky, 1984). 


\section{Subjective well-being}

Diener and associates (Suh, Diener, Oishi \& Triandis, 1998) consider subjective well-being to be an aspect of mental health and define it as a multidimensional construct that includes both cognitive and affective assessment of one's own life by an individual (Diener, Lucas \& Oishi, 2002). Cognitive assessment primarily concerns the concept of satisfaction from the perspective of an individual (life satisfaction, marriage satisfaction, job satisfaction) in relation to his personal criteria. The cognitive component refers to the global assessment of life satisfaction, but also to the assessment of satisfaction in individual domains of life. Subjective well-being encompasses several separate components: life satisfaction or satisfaction with various life domains, such as the marital and business domains, the way of spending free time, satisfaction with one's own household; the existence of positive feelings and moods over a period of time (pleasant emotions and moods); rare presence of negative feelings (depression, stress and anger) (Diener, 2000). People with a high degree of subjective well-being have predominantly positive assessments of their own lives and circumstances (Diener, 2000). The emotional aspect implies the frequency with which people experience pleasant emotions (joy) or unpleasant emotions (depression) (Diener, Lucas \& Oishi, 2002), which often occur together and intertwine during everyday life. A higher level of subjective well-being can directly, but also indirectly, affect health. Research shows that positive emotions improve the immune, cardiovascular, endocrine system of functioning, while negative emotions impair their health. Generally speaking, people who show a higher level of subjective well-being show a higher degree of health and fewer negative symptoms (DeNeve, Diener, Tay \& Xuereb, 2013).

\section{Self- efficacy}

Self- efficacy is a key concept in Bandura's theory of social cognitive development (Bandura, 1977). Self-efficacy in Bandura's opinion (Bandura, 2006a) is a differentiated set of self-beliefs related to different areas of functioning. Self-efficacy is the belief in one's own ability to use motivation, cognitive resources and actions to respond to demands in a given situation (Wood \& Bandura, 1989). People with high self-efficacy perceive difficult tasks as challenges to be overcome, not as threats to be avoided. They are deeply interested in what they do, set high goals for themselves and maintain a strong commitment to them. They explain failure by lack of information, lack of skills or insufficient effort, which can be corrected. If they encounter an obstacle, they are persistent in overcoming it and recover quickly after failure (Bandura, 2006b). In everyday life, self-efficacy determines the intensity of the effort that will be invested in dealing with difficulties, 
so they are more persistent people with a more developed sense of self-efficacy. In addition, self-efficacy determines the level of perceived control over life events and thus affects emotional reactions and exposure to stress (Bandura, 1995; 1997). The concept of self-efficacy is widely applicable, given that it can explain many determinants of individual behavior. It is encountered in research that considers psychological, social, emotional, and especially academic achievement (Bong \& Skaalvik, 2003). Academic self-efficacy refers to individual self-efficacy that is formed within academic domains, that is, academic self-efficacy refers to an individual's beliefs about their own achievement in certain academic tasks (Bong \& Skaalvik, 2003). Emotional self-efficacy refers to an individual's beliefs about their own ability to control their feelings. The emotional capacity of self-efficacy is reflected in a person's ability to cope with negative emotional experiences by acting on their intensity, frequency, and duration (Kirk, Schutte \& Hine, 2008). Social self-efficacy is an important aspect of a person's social skills related to the readiness to act in social conditions, i.e. the person's belief that he is capable of starting social contact and developing new friendships (Gecas, 1989). Thus, social self-efficacy is reflected in social courage, participation in a social group or activities, friendly behavior, and obtaining and providing assistance (Sherer, Maddux, Mercandante, Prentice-Dunn, Jacobs \& Rogers, 1982; Shim \& Finch, 2014; Smith \& Betz, 2000).

\section{Problem of Research}

The problem of the research was to examine the predictive power of parenting styles in predicting the self-efficacy and subjective well-being of adolescents. The findings so far show that the paternal and maternal figures have different contributions to certain outcomes in adolescent development, so this study specifically examined the contribution of fathers 'and mothers' educational styles in predicting self-efficacy and subjective well-being to determine their importance for optimal adolescent functioning.

\section{Methodology of Research}

\section{General Background of Research}

The theoretical basis of the paper consists of Diana Baumrind's model of parenting styles, Diner' model of subjective well-being and Bandura's model of self-efficacy. 


\section{Sample of Research}

The sample included 270 students from four high schools in Serbia, second and third grade, equal in gender, aged 16 and 17. Out of a total of 270 students, 113 male respondents (41.9\%) and slightly more female respondents 157 (58.1\%). Adolescents filled in their questionnaires at school, after the classes were over, for which the consent of the management of the schools in which the examination was conducted and the consent of the parents was obtained, considering that the examinees are minors.

\section{Instruments}

The following instruments were used in the research:

Parenting Styles and Dimensions Questionnaire (PSDQ) (Robinson, Mandleco, Olsen \& Hart, 2001) ontains the dimensions of authoritarian (coercion, verbal hostility and non-explanation) authoritative (connectivity, regulation and autonomy), and permissive style. The questionnaire as a whole contains 32 items and is of the Likert type. The reliability of the subscales ranges from $\alpha=.74$ to $\alpha=.87$.

The Self-Efficiency Questionnaire for Children ( SEQ-C) (Muris, 2001) is used to examine a child's experience of self-efficacy in three areas: social, academic and emotional. The questionnaire consists of 24 Likert-type items. The reliability of the subscales ranges from $\alpha=.72$ to $\alpha=.87$.

The short scale of subjective well-being - KSB (Jovanovic \& Brdaric, 2008) is intended for the global assessment of subjective well-being and consists of eight items divided into two subscales: positive affectivity and positive attitude towards life. The affective component is assessed using the positive affectivity subscale. The cognitive aspect of subjective well-being is assessed by the subscale positive attitude towards life. The reliability of the subscales ranges from $\alpha=.73$ to $\alpha=.86$.

\section{Results of research}

Tables 1 and 2 show the results of regression analysis in which the parenting styles of parents are predictor, and the subjective well-being of adolescents is a criterion variable.

When the father is perceived as a parent who indicates the connection between children's actions and consequences, then adolescents will show a positive attitude towards life, and when the father is assessed as someone who supports autonomy, adolescents will achieve greater subjective well-being. When the mother is perceived as emotionally warm and close, adolescents will show a positive attitude towards life. 
Table 1. Multiple regression analysis - assessed parenting styles as predictors of adolescent subjective well-being

\begin{tabular}{lccc}
\hline \multicolumn{1}{c}{ Predictors } & Positive affectivity & $\begin{array}{c}\text { A positive attitude } \\
\text { towards life }\end{array}$ & $\begin{array}{c}\text { Subjective } \\
\text { well-being } \\
\text { In total }\end{array}$ \\
\hline Father's parenting styles & $\beta$ & $\beta$ & $\beta$ \\
\hline Connected &, $214^{\star *}$ &, 113 &, $189^{\star}$ \\
\hline Regulation &, 019 &, $216^{* *}$ &, 120 \\
\hline Autonomy &, 111 &, 131 &, $135^{\star}$ \\
\hline Coercion &, 058 &, 050 &, 061 \\
\hline Verbal hostility &, 058 &, 012 &, 042 \\
\hline Non- explanation &,- 154 &,- 126 &,- 159 \\
\hline Permissiveness &, 005 &,- 030 &,- 012 \\
\hline $\mathrm{R}^{2}$ &, 122 &, 163 &, 170 \\
\hline Adjusted $\mathrm{R}^{2}$ &, 098 &, 141 &, 147 \\
\hline $\mathrm{F}$ & $5,130^{\star * *}$ & $7,196^{* * *}$ & $7,547^{\star * *}$ \\
\hline
\end{tabular}

${ }^{*} p<.05,{ }^{* *} p<.01,{ }^{* * *} p<.001$

Table 2. Multiple regression analysis - estimated maternal parenting styles as predictors of adolescent subjective well-being

\begin{tabular}{lccc}
\hline \multicolumn{1}{c}{ Predictors } & Positive affectivity & $\begin{array}{c}\text { A positive attitude } \\
\text { towards life }\end{array}$ & $\begin{array}{c}\text { Subjective well- be- } \\
\text { ing } \\
\text { In total }\end{array}$ \\
\hline Maternal parenting styles & $\beta$ & $\beta$ & $\beta$ \\
\hline Connected &, 090 &, $161^{\star}$ &, 137 \\
\hline Regulation &, 078 &, 122 &, 109 \\
\hline Autonomy &, 143 &, 102 &, 140 \\
\hline Coercion &, 028 &, 051 &, 043 \\
\hline Verbal hostility &, 052 &, 033 &, 049 \\
\hline Non- explanation &,- 026 &,- 051 &,- 042 \\
\hline Permissiveness &,- 028 &,- 029 &,- 032 \\
\hline $\mathrm{R}^{2}$ &, 066 &, 100 &, 100 \\
\hline Adjusted $\mathrm{R}^{2}$ &, 040 &, 076 &, 075 \\
\hline $\mathrm{F}$ & $2,614^{* *}$ & $4,146^{* * *}$ & $4,126^{* * *}$ \\
\hline
\end{tabular}

${ }^{*} p<.05,{ }^{* *} p<.01,{ }^{* *} p<.001$ 
Tables 3 and 4 show the results of regression analysis in which parenting styles are predictor variables, and adolescent self-efficacy is a criterion variable.

Table 3. Multiple regression analysis - assessed father's parenting styles as a predictor of adolescent self-efficacy

\begin{tabular}{lcccc}
\hline \multicolumn{1}{c}{ Predictors } & $\begin{array}{c}\text { Social self- } \\
\text { efficacy }\end{array}$ & $\begin{array}{c}\text { Academic self- } \\
\text { efficacy }\end{array}$ & $\begin{array}{c}\text { Emotional } \\
\text { self- efficacy }\end{array}$ & $\begin{array}{c}\text { Self- efficacy } \\
\text { In total }\end{array}$ \\
\hline Father's parenting styles & $\beta$ & $\beta$ & $\beta$ & $\beta$ \\
\hline Connected &, 064 &, 090 &, 087 &, 097 \\
\hline Regulation &, 135 &, $264^{* *}$ &, 153 &, $232^{\star *}$ \\
\hline Autonomy &, $211^{\star *}$ &, 106 &, $149^{*}$ &, $187^{\star}$ \\
\hline Coercion &,- 014 &, 074 &,- 103 &,- 013 \\
\hline Verbal hostility &, 064 &,$- 223^{* *}$ &, 000 &,- 075 \\
\hline Non- explanation &,- 129 &,- 110 &,- 054 &,- 125 \\
\hline Permissiveness &,- 107 &,- 035 &,$- 155^{\star}$ &,- 118 \\
\hline $\mathrm{R}^{2}$ &, 140 &, 212 &, 138 &, 228 \\
\hline Adjusted $\mathrm{R}^{2}$ &, 117 &, 191 &, 114 &, 207 \\
\hline $\mathrm{F}$ & $6,018^{\star * *}$ & $9,932^{* * *}$ & $5,882^{* * *}$ & $10,912^{* * *}$ \\
\hline
\end{tabular}

${ }^{*} p<.05,{ }^{* *} p<.01,{ }^{* *} p<.001$

Table 4. Multiple regression analysis - estimated maternal parenting styles as predictors of adolescent self-efficacy

\begin{tabular}{lcccc}
\hline \multicolumn{1}{c}{ Predictors } & $\begin{array}{c}\text { Social self- } \\
\text { efficacy }\end{array}$ & $\begin{array}{c}\text { Academic self- } \\
\text { efficacy }\end{array}$ & $\begin{array}{c}\text { Emotional } \\
\text { self- efficacy }\end{array}$ & $\begin{array}{c}\text { Self- efficacy } \\
\text { In total }\end{array}$ \\
\hline Maternal parenting styles & $\boldsymbol{\beta}$ & $\boldsymbol{\beta}$ & $\boldsymbol{\beta}$ & $\boldsymbol{\beta}$ \\
\hline Connected &, 037 &, 053 &, 014 &, 045 \\
\hline Regulation &, 128 &, $260^{\star *}$ &, 075 &, $195^{\star *}$ \\
\hline Autonomy &, $272^{\star *}$ &, 103 &, $182^{\star}$ &, $223^{* *}$ \\
\hline Coercion &,- 046 &, 135 &,$- 175^{\star}$ &,- 033 \\
\hline Verbal hostility &,- 036 &,- 125 &, 077 &,- 039 \\
\hline Non- explanation &, 050 &,$- 193^{\star}$ &, 009 &,- 061 \\
\hline Permissiveness &,- 046 &,- 082 &,- 053 &,- 074 \\
\hline $\mathrm{R}^{2}$ &, 149 &, 170 &, 083 &, 173 \\
\hline Adjusted $\mathrm{R}^{2}$ &, 127 &, 149 &, 058 &, 150 \\
\hline $\mathrm{F}$ & $6,553^{* * *}$ & $7,645^{\star * *}$ & $3,362^{\star * *}$ & $7,757^{\star * *}$ \\
\hline
\end{tabular}

${ }^{*} p<.05,{ }^{* *} p<.01,{ }^{* * *} p<.001$ 
If the father is perceived as a parent who respects the opinion and needs of the child when making important decisions for the family, adolescents will achieve social, emotional and overall self-efficacy. However, when the father is critical of the child, the adolescent will be less academically self-effective, and when the father is permissive, adolescents will not achieve emotional self-efficacy. When adolescents perceive the mother as someone who explains to them the rules and the connection between the behavior and the consequences of that behavior, adolescents will show greater academic and overall self-efficacy. When the mother is perceived as someone who cares about the child's opinion, adolescents will have a sense of social and emotional self-efficacy. However, when the mother uses corporal punishment in upbringing, adolescents will be less emotionally self-effective, and when the mother does not explain the rules she imposes on the child, then adolescents will be less academically self-effective.

\section{Discussion}

Parental assessment is an important aspect of family assessment, given that there is evidence of the impact of parental behavior on a child's social, emotional development, as well as on academic achievement (Everett-Bailey, 2005). The provision of support, love and encouragement by the father towards the child (high connection) leads to adolescents developing an experience of academic and overall self-efficacy. When the father encourages the child to express his thoughts, feelings and desires, allows the child to make decisions in accordance with his abilities (high autonomy), there is a great opportunity for adolescents to develop an experience of social self-efficacy. When the father is warm, but has no demands and allows the child to make decisions before he is ready for them, it is possible that adolescents do not develop a sense of self-efficacy. A mother who is sensitive to the needs of the child and respects the opinion when making important decisions for the family, probably in this way promotes the development of the child's self-efficacy experience. When the mother is more inclined to achieve obedience of the child through physical punishment (high coercion), it is possible that adolescents lose control of their emotions and do not have a developed experience. Even Baumrind (1968) in her research found that children of authoritative parents are emotionally more mature, socially independent, more active and successful than children who had authoritarian or permissive parents. According to Baumrind and Thompson (2002) the authoritative parent develops the child's social competence through joint activities and conversations 
and relies on persuasion, not coercion. Such a parent respects the child's opinion, recognizes the child's current qualities, sets standards for future behaviors, thus giving the child the basis and support to achieve their goals. Emotionally warm and supportive parents who respect the needs and opinions of children, will create an environment that encourages positive affectivity in adolescents and an optimistic attitude towards the outcomes of their activities. In children, the process of self-realization is encouraged, an optimistic approach to tasks and life problems in general. Authoritative parenting contributes to the development of competencies, and encourages the development of resilience to a range of negative influences, including stressful events and antisocial peers (Maccoby \& Martin, 1983). Children raised in a democratic environment in which one loves unconditionally, nurtures freedom of thought and emotion, participates in decision-making, learns how to be responsible, is allowed to behave autonomously, develops self-confidence and a sense of subjective well-being (Deniz, Karakuş, Traş, Eldeleklioglu, Özyeşil \& Hamarta, 2013). Also, the results of the research show that greater physical presence, competence and emotional involvement of the father are significantly associated with the feeling of general satisfaction in young people (Harris, Furstenberg \& Marmer, 1998; Krampe \& Newton, 2006).

\section{Conclusions}

Authoritarian parenting style contributes to adolescents' development of self-efficacy and subjective well-being, which is in line with Diana Baumrind's initial model of parenting style: authoritative parents - through high warmth and control - provide the child with an optimal environment for development. The role of the father is more important in the development of self-efficacy and subjective well-being in adolescents than the role of the mother.

\section{References}

Bandura, A. (1977). Self-efficacy: Toward a Unifying Theory of Behavioral Change. Psychological Review, 84 (2), 191-215.

Bandura, A. (1995). Exercise of personal and collective efficacy in changing societies. In Bandura, A. (ed.).Self-efficacy in changing societies. New York: Cambridge University Press. 1-45.

Bandura, A. (1997). Self-efficacy. Harvard mental health letter, 13 (9), 4-6.

Bandura, A. (2006a). Guide for constructing self-efficacy scales. Self-Efficacy Beliefs of Adolescents, 307-337. 
Bandura, A. (2006b). Adolescent Development from an Agentic Perspective. U: Pajares, F., Urdan, T. (ed.). Self-efficacy and adolescents. USA: Information Age Publishing, 1-45.

Baumrind, D. (1966). Effects of Authoritative Parental Control on Child Behavior. Child Development, 37(4), 887-907.

Baumrind, D. (1968). Authoritarian vs. authoritative parental control. Adolescence, 3 (11), 255-272.

Baumrind, D. (1991). The influence of parenting style on adolescent competence and substance use. Journal of Early Adolescence, 11, 56-95

Baumrind, D., Thompson, A.R. (2002). The Ethics of Parenting, In M. Bornstein (Ed.). Handbook of Parenting, 5, Practical Issues in Parenting, LEA, Mahwah, New Jersey London.

Belsky, J. (1984). The determinants of parenting: A process model. Child development, 83-96.

Belsky, J. \& Domitrovich, C., Crnic, K. (1997). Temperament and Parenting Antecedents of Individual Differences in Three-Year-Old Boys' Pride and Shame Reactions. Child Development, 68 (3), 456-466.

Bong, M. \& Skaalvik, E.M. (2003). Academic Self-Concept and Self-Efficacy: How Different Are They Really? Educational Psychology Review. 15 (1), 1-40.

Deniz, M.E., Karakuş, O., Traş, Z., Eldeleklioglu, J., Özyeşil Z. \& Hamarta, E. (2013). Parental Attitude Perceived by University Students as Predictors of Subjective Well-Being and Life Satisfaction. Scientific Research, Psychology, 4(3), 169173.

DeNeve, J.E., Diener, E., Tay L. \& Xuereb, C. (2013). The Objective Benefits of Subjective WellBeing. U J. Helliwell, R. Layard, \& J. Sachs (ed.) World Happiness Report 2013. New York: UN Sustainable Development Solutions Network.

1Diener, E. (2000). Subjective Well-Being. The science of happiness and Proposal for a National Index. American Psychologist, 55(1), 34-43.

Diener, E., Lucas, R.E. \& Oishi, S. (2002). Subjective Well - Being: The Science of Happiness and Life Satisfaction, in Snyder, C.R. \& Lopez, S.J. (ed.). Handbook of positive psychology. New York: Oxford University Press, 63-73.

Everett-Bailey, C. (2005). Assessment of Parenting Styles and Behavior. In: Cierpka, M., Thomas, Y., Sorenkle, D.H. (ed.). Family Assessment: Integrating Multiple Perspectives. Cambridge, Hogrefe.

Gecas, V. (1989). The social psychology of self-efficacy. Annual Review of Sociology, 15, 291-316.

Harris, K., Furstenberg, F., \& Marmer, J. (1998). Paternal involvement with adolescents in intact families: the influence of father over the life course. Demography, 35, 201-216.

Jovanovic, V. \& Brdaric, D. (2008). Short scale of subjective well-being. Unpublished manuscript, Novi Sad: University of Novi Sad.

Kirk, B.A., Schutte, N.S. \& Hine, D.W. (2008). Development and preliminary validation of an emotional self- efficacy scale. Personality and Individual Differences, 45, 432-436.

Krampe, E. \& Newton, R. (2006). The father presence questionnaire: a new measure of the subjective experience of being fathered. Fathering, 4, 159-190. 
Maccoby, E.E. \& Martin, J.A. (1983.). Socialization in the context of the family: Parent-child interaction. U: Mussen, P.H. \& Hetherington, E.M. (ed.), Handbook of child psychology, 4. Socialization, personality, and social development (4 ${ }^{\text {th }}$ ed.). New York: Wiley, 1-101 .

Muris, P. (2001). A bref questionnaire for measuring self-efficacy in youths. Journal of Psychopathology and Behavioral Assessment, 23 (3), 145-149.

Pavicevic, M. (2020). Personality traits and parenting styles as predictors of self-efficacy, subjective well-being and psychopathic tendencies of adolescents. Doctoral dissertation. University of Nis, Faculty of Philosophy.

Robinson, C.C., Mandleco, B., Olsen, S.F. \& Hart, C.H. (2001). The Parenting Styles and Dimensions Questionnaire (PSDQ). In B.F. Perlmutter, J. Touliatos, \& G.W. Holden (ed.). Handbook of family measurement techniques, 3. Instruments \& index, Thousand Oaks: Sage. 319-321.

Sherer, M., Maddux, J.E., Mercandante, B., Prentice-Dunn, S., Jacobs, B. \& Rogers, R.W. (1982). The self-efficacy scale: Construction and validation. Psychological Reports, 51 (2), 663-671.

Shim, S.S. \& Finch, W.H. (2014). Academic and social achievement goals and early adolescents' adjustment: A latent class approach. Learning and Individual Differences, 30, 98-105.

Suh, E., Diener, E., Oishi, S. \& Triandis, H.C. (1998). The shifting basis of life satisfaction judgments across cultures: Emotions versus norms. Journal of Personality and Social Psychology, 74, 482-493.

Wood, R.E. \& Bandura, A. (1989). Impact of conceptions of ability on self-regulatory mechanisms and complex decision making. Journal of Personality and Social Psychology, 56 (3), 407-415. 